\title{
Peripheral neuropathy and solitary myeloma: analysis of serum and CSF IgG in two cases
}

\author{
C MILANESE, ${ }^{*} S$ PROCACCIA,$\dagger$ L LA MANTIA, ${ }^{*}$ E GUZZETTI, $\dagger$ F CORRIDORI* \\ From the Department of Neurology, Istituto Neurologico C Besta, ${ }^{*}$ and the Department of Serology, Istituto \\ di Clinica Medica IV, Universita' degli Studi, † Milan, Italy
}

SUMmARY Clinical and laboratory findings of two patients affected by solitary myeloma, $\mathrm{IgG}_{3}$ lambda type, with peripheral neuropathy are reported. In both cases the same IgG isoelectrofocusing pattern was found in cerebrospinal fluid and serum samples. Data are consistent with damage of the blood-brain barrier.

Peripheral neuropathy is a well-known complication of myeloma ${ }^{1-9}$ and other paraproteinaemias, such as Waldenstrom macroglobulinaemia, ${ }^{10-12}$ benign gammopathies ${ }^{13-15}$ and cryoglobulinaemia, ${ }^{16-18}$ but its pathogenesis is still unknown. Cerebrospinal fluid (CSF) proteins usually are increased, but accurate analysis of CSF rarely has been reported..$^{1315}$ In this paper serum and CSF protein analysis in two patients with polyneuropathy and solitary myeloma are described.

\section{Case reports}

Case 1 A 45-year-old man was admitted after an 18 months history of increasing difficulty in walking associated with numbress of the feet. Moderate wasting of proximal muscles of the arms and weakness of distal muscles of the lower limbs were present; deep reflexes were absent and vibration sense was decreased. Electromyographic findings confirmed a diffuse peripheral neuropathy involvement. Serum immunoelectrophoresis (IEP) revealed a monoclonal IgG. IgA and IgG were slightly increased (IgG $22.90 \mathrm{~g} / \mathrm{l}$, normal value (nv) 8.00-18.00 g/l; IgA $4.22 \mathrm{~g} / \mathrm{l}$, nv $1.5-4 \mathrm{~g} / \mathrm{l}$, IgM was normal $(0.52 \mathrm{~g} / \mathrm{l}$, nv 0.6-3 g/l). Cryoglobulins and Bence-Jones protein were absent. Total CSF protein $(1.41 \mathrm{~g} / \mathrm{l}$, nv $0.20-0.45 \mathrm{~g} / \mathrm{l}), \mathrm{IgG}$ $(0.249 \mathrm{~g} / \mathrm{l}$, nv 0.008-0.03 $\mathrm{g} / \mathrm{l})$ and albumin $(6.78 \mathrm{~g} / \mathrm{l}$, nv $0.12-0.29 \mathrm{~g} / \mathrm{l})$ were increased; IgG index was normal $(0.56$, nv less than 0.78$)$; IEP revealed a monoclonal IgG. Three months later, after steroid therapy, the monoclonal

Address for reprint requests: Dr C Milanese, Department of Neurology, Instituto Neurologico C Besta, via Celoria 11, Milan, Italy.

Received 7 August 1981 and in revised form 17 December 1981. Accepted 25 January 1982
IgG was still present in serum and CSF. No intrathecal synthesis of IgG was detected. Radiological examination revealed a lytic lesion of the sacrum, suggestive of plasmocytoma. Bone marrow examination was normal. A marked remission of the neurological condition was observed 8 months after local radiotherapy (total dose 3600 rads). Bone marrow examination still was normal.

Case 2 A 60-year-old man was admitted after a 14 months history of numbness in the feet followed by increasing difficulty in walking. Bilateral foot drop and wasting of distal muscles of the lower limbs were present. Deep reflexes were absent; vibration and position sense were impaired. Electromyographic findings confirmed peripheral nerve involvement. Serum IEP revealed a monoclonal IgG. Immunoglobulin levels were normal (IgA $2.26 \mathrm{~g} / \mathrm{l} ;$ IgG $12.5 \mathrm{~g} / \mathrm{l}$; IgM $1.58 \mathrm{~g} / \mathrm{l})$. Cryoglobulins and Bence-Jones protein were absent. Total CSF protein (1.9 $\mathrm{g} / \mathrm{l}), \mathrm{IgG}(0.15 \mathrm{~g} / \mathrm{l})$ and albumin $(0.9 \mathrm{~g} / \mathrm{l})$ were increased; IgG index $(0.49)$ was normal. No intrathecal synthesis of IgG was detected. IEP revealed a monoclonal IgG. Radiological examination showed an osteolyticosteosclerotic lesion of the 9th thoracic vertebra, suggestive of plasmocytoma. Bone marrow examination was normal. Biopsy and histological examination of the vertebral lesion led to the diagnosis of lymphoma with plasma cell differentiation; immunohistological stains showed IgG lambda light chains to be present within the tumour cells. In spite of local radiotherapy (total dose 4200 rads) followed by chemotherapy (melphalan and prednisone), his neurological condition detriorated: and 26 months after the onset, severe wasting, predominantly affecting the distal muscles was present.

\section{Methods}

CSF samples were assayed for protein levels immediately after collection and concentrated to the optimal protein 
level for electrofocusing. Serum and concentrated CSF samples were frozen at $-20^{\circ} \mathrm{C}$, and thawed only before examination. Serum samples initially were precipitated with $18 \% \mathrm{Na}_{2} \mathrm{SO}_{4}$, according to Kekwich; ${ }^{19}$ the precipitate was purified for IgG by ion-exchange chromatography with DEAE cellulose (Whatman DE 52) equilibrated with 0.01 $\mathrm{M}$ phosphate buffer, $\mathrm{pH}$ 8. The purity of the IgG preparation was checked by immunoelectrophoresis and by double radial immunodiffusion (Ouchterlony). To avoid loss of material, CSF IgG was not purified: the quantitation of the other classes of immunoglobulins indicated that no IgM and negligible IgA were present. Isoelectric focusing was carried out on LKB ampholine ready-prepared thin-layer polyacrylamide gels (PAG plates, LKB, Stockholm, Sweden) $\mathrm{pH}$ range 3.5-9.5. Fifteen $\mu \mathrm{l}$ of CSF and serum samples (IgG concentration 1 to $5 \mathrm{~g} / \mathrm{l}$ ) were applied on the middle of the gel. One $\mathrm{M} \mathrm{H}_{3} \mathrm{PO}_{4}$ at the anode and $1 \mathrm{M}$ $\mathrm{NaOH}$ at the cathode were used as electrode solutions. The running conditions were established by setting the LKB 2103 power supply at $10^{\circ} \mathrm{C}$ at $P=30, U=1500 \mathrm{~V}$ and $I=50 \mathrm{~mA}$. The time for experiment was $1.5 \mathrm{hr}$. The $\mathrm{pH}$ gradient at the end of the run was determined by surface electrode (type 205 403-30 N8, Ingold, Zurich, Switzerland). The zones were thereafter refocused for an additional $10 \mathrm{~min}$. The gels were then processed following the standard supplied instructions.

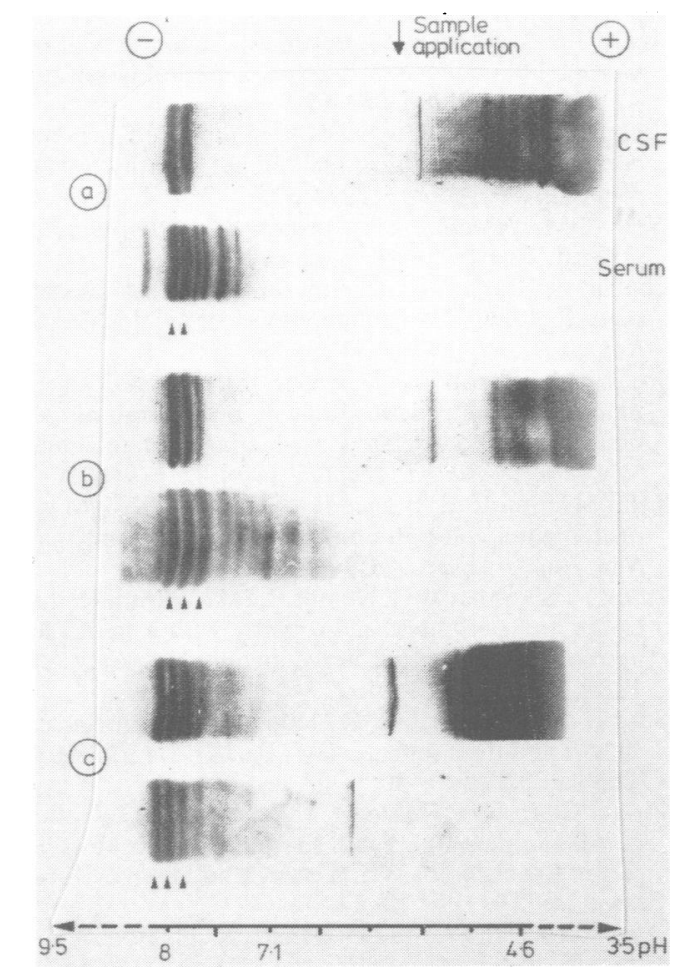

Figure Whole CSF (above) and serum IgG (below) isoelectrofocusing pattern of case $1(a, b)$ and case $2(c)$.

\section{Results}

The figure shows the isoelectric pattern of whole CSF and serum IgG of case $1(a, b)$ and case $2(c)$. The first CSF examination of case 1 (fig (a)) showed two bands at $\mathrm{pH} 7.7$ and 8 . The same bands were present in the serum together with other bands at pH between 7.6 and 7.3. Three months later a new band at $\mathrm{pH} 7.6$ was demonstrated in CSF; this component, already present in the first serum sample, was better represented in the second serum sample (fig (b)). A clear correlation between serum and CSF IgG bands also was demonstrated in case 2 (fig (c)): three major bands between $\mathrm{pH} 7.8$ and $\mathbf{8 . 2}$ were present both in serum and CSF. The physicochemical analogy of serum and CSF IgG was strengthened by the results concerning the distribution of IgG subclasses, determined by double radial immunodiffusion (table): the prevalence of the IgG 3 subclass was noteworthy. The light chain characterisation of paired serum and CSF samples, performed by immunoelectrophoresis, defined the lambda type of paraprotein in both cases. Consequently the $\operatorname{IgG}$ kappa:lambda ratio determined in all CSF samples was steadily inversed.

Table CSF and serum IgG subclass distribution, expressed in terms of intensity of the precipitation bands

\begin{tabular}{lllll}
\hline Patient & $I g G_{1}$ & $I_{g} G_{2}$ & $I g G_{3}$ & $I g G_{4}$ \\
\hline Case 1 (first sample) & \pm & - & ++ & + \\
Case 1 (second sample) & \pm & - & ++ & + \\
Case 2 & \pm & - & ++ & + \\
\hline$-=$ absent & & & & \\
$\pm=$ very light & & & & \\
$+=$ light & & & & \\
$++=$ marked & & &
\end{tabular}

\section{Discussion}

Our two patients presented with a chronic motorsensory neuropathy. In both cases the presence of a serum monoclonal IgG lambda associated with a single bone lesion led to the diagnosis of solitary myeloma. The association of neuropathy and myeloma is well-established, but its pathogenesis remains controversial. Since neuropathy is a common complication of paraproteinaemias accompanying different clinical conditions, attention has been focused on the abnormal protein itself.

Deposits of the paraprotein in the peripheral nervous tissue have been demonstrated by immunofluorescence studies, ${ }^{101120}$ but their specificity is debated. ${ }^{21}$ An antibody activity to human myelin has been demonstrated by $\mathrm{Kahn}^{22}$ and Latov $^{23}$ in cases of IgM paraproteinaemic 
neuropathy. Different pathogenetic mechanisms might be involved in different kinds of paraproteinaemias, possibly related to their specific physico-chemical or biological properties. Since deposition of light chain protein has been demonstrated also in the neural vassels, ${ }^{15}$ a primitive pathogenetic role of a damage of the blood-nerve barrier may be suggested.

Our data clearly indicate the existence of damage to the blood-brain barrier: in both cases CSF albumin was increased, IgG index was normal, and no intrathecal synthesis of $\mathrm{IgG}$ was detected. The same IgG lambda, with the identical isoelectrofocusing pattern, was found in serum and CSF. The peripheral origin of the CSF paraprotein is confirmed by the finding of a new band in the second CSF sample of case 1 , which was already present in the serum three months before. The finding that IgG belonged to type 3 subclass must be emphasised. Well-known properties of IgG 3 are complement fixing capacity, high incidence of cryoprecipitability, and tendency to degrade to Fab and Fc fragments which may in turn bind together to form immunocomplex-like molecules. ${ }^{24-26}$ Whether or not, and how (directly or through damage of the blood-nerve barrier), these properties are relevant in the genesis of the neuropathy is only speculative. Systematic studies of serum and CSF immunoglobulins, with particular attention to their heavy and light chain composition, subclass identification and isoelectrofocusing pattern, might contribute to clarify the pathogenesis of myeloma neuropathy.

\section{References}

${ }^{1}$ Victor M, Banker B, Adams RD. The neuropathy of multiple myeloma. J Neurol Neurosurg Psychiatry 1958;21:73-88.

2 Silverstein A, Doniger DE. Neurological complications of myelomatosis. Arch Neurol 1963;9:102-12.

${ }^{3}$ Aguayo A, Thompson DW, Humphrey JG. Multiple myeloma with polyneuropathy and osteosclerotic lesions. $J$ Neurol Neurosurg Psychiatry 1964;27:562-6.

4 Rushton DI. Peripheral sensory-motor neuropathy associated with a localized myeloma. $\mathrm{Br}$ Med J 1965;2:203-5.

5 Walsh JC. The neuropathy of multiple myeloma. Arch Neurol 1971;25:404-14.

- Davis LE, Drachman DB. Myeloma neuropathy. Arch Neurol 1972:27:507-11.

${ }^{7}$ McLeod JC, Walsh JC. Neuropathies associated with paraproteinemias and disproteinemias. In: Dick PJ, Thomas PK, Lambert EH, eds. Peripheral Neuropathy vol 2. Philadelphia: WB Saunders, 1975:1012-29.

sead D, Warlow C. Peripheral neuropathy and solitary plasmocytoma. J Neurol Neurosurg Psychiatry 1978;41:177-84.

' Kelly JJ, Kyle RA, Miles JM, O'Brien PC, Dyck PJ. The spectrum of peripheral neuropathy in myeloma. Neurology (NY) 1981;31:24-31.

${ }^{10}$ Iwashita H, Argyrakis A, Lowitzsch $\mathrm{K}$, et al. Polyneuropathy in Waldenstrom's macroglobulinemia. J Neurol Sci 1974;21:341-54.

"Propp RP, Means E, Deibel R, Sherer G, Barron K. Waldenstrom's macroglobulinemia and neuropathy. Neurology (Minneap) 1975;25:980-6.

${ }^{12}$ Dalakas MC, Flaum M, Engel WK, et al. Successful treatment of a Waldenstrom macroglobulinemic polyneuropathy. Role of dysproteinemia in the pathogenesis of the neuropathy. Neurology (Minneap) 1980;30:168.

${ }^{13}$ Contamin F, Singer B, Mignot R, et al. Polyneuropathie a rechutes, evoluant depuis 19 ans, associée à une gamopathie monoclonale IgG benigne. Rev Neurol (Paris) 1976;132:741-62.

14 Read DJ, Vanhegan RI, Matthews WB. Peripheral neuropathy and benign IgG paraproteinemia. $J$ Neurol Neurosurg Psychiatry 1978;41:215-9.

${ }^{15}$ Dalakas MC, Engel WK. Polyneuropathy with monoclonal gammopathy: studies of 11 patients. Ann Neurol 1981;10:45-52.

${ }^{16}$ Abramsky O, Slavin S. Neurological manifestations in patients with mixed cryoglobulinemia. Neurology (Minneap) 1974;24:245-9.

17 Vallat JM, Desproges-Gotteron R, Leboutet MJ, et al. Cryoglobulinemic neuropathy: a pathological study. Ann Neurol 1980;8:179-85.

18 Cream JJ, Hera JE, Hughes RA, et al. Mixed or immune complex cryoglobulinaemia and neuropathy. J Neurol Neurosurg Psychiatry 1974;37:82-7.

19 Weir DM. Handbook of experimental immunology. Oxford: Blackwell, 1973, cp 6,7.

${ }^{20}$ Chazot G, Berger B, Carrier H, et al. Manifestation neurologiques des gammopathies monoclonales. Rev Neurol (Paris) 1976;132 (3):195-212.

${ }^{21}$ Swash M, Perrin J, Schwartz MS. Significance of immunoglobulin deposition in peripheral nerve in neuropathies associated with paraproteinaemia. $J$ Neurol Neurosurg Psychiatry 1979;42:179-83.

${ }^{22}$ Kahn SN, Smith IS, Eames RA, Thomas PK. IgM paraproteinemia and autoimmune peripheral neuropathy. New Engl J Med 1981;304 (23):1430-1.

${ }^{23}$ Latov N, Sherman WH, Nemni R, et al. Plasma-cell dyscrasia and peripheral neuropathy with a monoclonal antibody to peripheral-nerve myelin. New Engl J Med 1980;303 (11):618-21.

${ }^{24}$ Shakib F, Stanworth DR. Human IgG subclasses in health and disease (a review) Part II. La Ricerca Clin Lab 1980;10:561-80.

${ }^{25}$ Virella G, Hobbs JR. Heavy chain typing in IgG monoclonal gammopathies with special reference to cases of serum hyper-viscosity and cryoglobulinemia. Clin Exp Immunol 1971;9:973-84.

${ }^{26}$ Saluk PH, Clem W. Studies on the cryoprecipitation of a human IgG cryoglobulin: the effect of temperature induced conformational changes on the primary interaction. Immunochemistry 1975;2:29-37. 